ISSN: 2548-1843

EISSN: 2621-8704

\title{
PENGARUH PROGRESSIVE MUSCLE RELAXATION (PMR) TERHADAP MYALGIA PADA PASIEN KANKER PARU YANG MENJALANI KEMOTERAPI
}

\author{
Dedeh Komalawati ${ }^{1}$ ), Lestari Sukmarini ${ }^{1}$ ), Tuti Herawati ${ }^{1}$ ) \\ 1) FIK, Universitas Indonesia, Kampus UI Depok, 16426, Indonesia \\ E-mail : dedeh_rsp@yahoo.co.id
}

\begin{abstract}
ABSTRAK
Myalgia dapat terjadi karena efek samping kemoterapi. Tujuan penelitian ini adalah mengetahui pengaruh PMR terhadap myalgia pada pasien kanker paru yang menjalani kemoterapi. Penelitian ini menggunakan desain quasi experiment dengan pre-post test with control group. Sampel penelitian adalah 32 orang, diambil dengan consecutive sampling. Pengukuran intensitas myalgia dilakukan dengan menggunakan numeric rating scale. Kelompok intervensi diberikan tindakan PMR selama 15 menit dengan frekuensi 2x sehari dalam 5 hari berturut-turut pasca kemoterapi. Hasil penelitian didapatkan penurunan intensitas myalgia sebelum dan setelah dilakukan intervensi pada kelompok intervensi ( $\mathrm{p}$ value 0,001) dan pada kelompok kontrol ( $\mathrm{p}$ value 0,001). Namun terdapat perbedaan penurunan intensitas myalgia antara kelompok kontrol dan kelompok intervensi setelah diberikan intervensi dengan selisih 0,81 $(p$ value $=0,001)$. Kesimpulan, PMR dapat membantu menurunkan myalgia pada pasien kanker paru yang menjalani kemoterapi. PMR dapat menjadi salah satu terapi komplementer yang bisa diterapkan perawat di rumah sakit untuk menurunkan myalgia.
\end{abstract}

Kata kunci : Kanker paru, kemoterapi, myalgia, progressive muscle relaxation

\begin{abstract}
Myalgia can be occured by side effect of chemotherapy. The purpose of this study was to identify the effect of PMR against myalgia in lung cancer patients undergoing chemotherapy. This study design was a quasi experiment, used pre and post test with control group. Samples were 32 patients, recruited by consecutive sampling. Measuring pain assessment used numeric rating scale. The intervention group had been provided PMR fifteen minutes twice a day for five days post chemotherapy. The results showed significantly different reduction of pain intensity before and after providing PMR in the intervention group and control group as well ( $p$ value $=0,001$ ). There was a significantly different reduction of myalgia intensity between both group after giving intervention with mean difference 0,81 ( $p$ value $=0,001$ ). It can be concluded that PMR can reduce myalgia in lung cancer patients undergoing chemotherapy. Suggestion, PMR becomes one of the complementary therapies to overcome myalgia.
\end{abstract}

Keywords: Chemotherapy, lung cancer, myalgia, progressive muscle relaxation

JKH/ Volume 2/ Nomor 2/Juli 2018 (ISSN: 2548-1843, EISSN: 2621-8704) 


\section{PENDAHULUAN}

Kanker menjadi satu masalah kesehatan utama baik di dunia maupun di Indonesia. Insiden kanker di dunia dari tahun 2008 sampai 2012 meningkat 14,1 juta kasus, sedangkan jumlah kematian meningkat sebesar 8,2 juta. Sekitar 1,59 juta diantaranya meninggal karena kanker paru. Kanker paru menempati posisi pertama dengan jumlah kematian terbanyak. Kanker paru termasuk dalam 5 jenis kanker terbanyak di dunia (WHO, 2013).

Penatalaksanaan pada kanker paru yaitu pembedahan, radiasi dan kemoterapi (Smeltzer, 2008). Kemoterapi merupakan pilihan pengobatan pada pasien kanker paru terutama Small Cell Lung Cancer (PDPI, 2011). Adapun obat kemoterapi yang biasa digunakan pada kanker paru adalah carboplatin, cisplatin, etoposide, docetaxel, gemcitabine, paclitacsel, pemetrexed, irinotecan dan vinorelbin

(Falk \& Williams, 2010).

Tujuan kemoterapi adalah menghancurkan sel-sel tumor tanpa kerusakan berlebih pada sel-sel normal (Black \& Hawk, 2014). Efek samping kemoterapi antara lain myagia, mual, muntah, rambut rontok sampai botak, mukositis, kesemutan, diare, menurunkan produksi sel darah, lelah/fatigue, dan bahkan alergi (Suryo, 2010). Efek samping kemoterapi dengan obat carboplatin dan paclitacsel yang sering dikeluhkan pasien adalah myalgia dan arthralgia (Yoshida at al., 2009). Efek samping dari carboplatin dan etoposide adalah myalgia ringan sampai sedang (Philips, 2013).

Myalgia adalah sensasi ketidaknyamanan kram, rasa nyeri seperti ditusuk-tusuk (Rohkamm, 2013). Myalgia merupakan nyeri yang berasal dari otot dan berhubungan dengan lokasi otot yang terkena (Davey, 2006). Myalgia adalah proses inflamasi dan pada umumnya terjadi karena reaksi reflek spasme otot dan bisa terjadi di seluruh bagian tubuh (Handoko, 2008). Adapun gejala myalgia adalah pegal, linu, berdenyut dan terasa sakit bila ditekan (Handoko, 2008). 
Rasa nyeri merupakan pengalaman emosional dan sensori yang tidak menyenangkan serta berhubungan dengan kerusakan jaringan baik bersifat aktual maupun potensial (Otto, 2001). Nyeri harus diidentifikasi sebelum dilakukan terapi, saat dilakukan terapi dan setelah dilakukan terapi (Strong et al, 2002). Apabila klien mengeluh nyeri perlu dilakukan penilaian rasa nyeri yang bisa dilakukan dengan pengkajian PQRST yaitu: provoking incident, quality of pain, region radiation, relief severity (scale) of pain dan time (Muttaqin, 2008). Pengukuran nyeri dari aspek severity atau scale dapat dilakukan dengan numeric rating scale, face pain rating scale dan visual analog scale.

Penatalaksanaan myalgia pada pasien yang menjalani kemoterapi terdiri dari terapi farmakologi dan nonfarmakologi. Terapi farmakologi yaitu nonopioid dan opiate. Terapi nonfarmakologi Progressive muscle relaxation (PMR) merupakan metode yang berfokus pada relaksasi otot, diciptakan pertama kali oleh dr Edmund Jacobson (Greenberg,
2002). PMR memodifikasi nyeri, memungkinkan terjadi relaksasi otot yang akan merangsang pengeluaran endorfin dan menghambat transmisi nyeri ke medulla spinalis serta otak sebagai pusat rasa sakit sehingga persepsi nyeri menurun (Rohads, 2013). Penelitian ini dilakukan untuk mengetahui pengaruh PMR terhadap myalgia pada pasien kanker paru yang menjalani kemoterapi.

\section{METODE}

Penelitian ini merupakan penelitian kuantitatif yang emnggunakan rancangan quasi experiment control group yaitu untuk mengetahui pengaruh PMR terhadap myalgia pada pasien kanker paru yang menjalani kemoterapi. Sampel penelitian ini terdiri dari 32 pasien kanker paru yang menjalani kemoterapi dan instrumen yang digunakan yaitu form numeric rating scale untuk mengukur intensitas myalgia. Pada kelompok intervensi yaitu memberikan PMR selama 15 menit dengan frekuensi $2 \mathrm{x}$ sehari dalam 5 hari berturut-turut pasca kemoterapi. sedangkan pada kelompok kontrol yaitu memberikan analgetik kemudian dilakukan postest 
baik pada kelompok intervensi maupun kelompok kontrol untuk mengetahui intensitas myalgia.

\section{HASIL}

\section{Analisis univariat}

Pada penelitian ini rerata usia responden yaitu $50,13 \mathrm{SD} \pm 12,66$ dengan rerata 46.69 $\mathrm{SD} \pm 14.10$, jenis kelamin mayoritas laki-laki $(81,3 \%)$, jenis analgetik mayoritas asam mefenamat (90,6\%), obat kemoterapi yang dugunakan carboplatin dan paklitaksel $(68,7 \%)$, siklus kemoterapi mayoritas kurang dari $3(81,3 \%)$.

\section{Analisis bivariat}

Pada penelitian ini intensitas myalgia pre dan post test pada kelompok kontrol maupun intervensi pada tabel 1 menunjukkan pengaruh intervensi yang diberikan pada kelompok kontrol dan kelompok intervensi. Hasil uji statistik menunjukkan ada perbedaan rerata intensitas myalgia pada kelompok kontrol dan kelompok intervensi ( $p$ value $=$ 0,001). Pada tabel 2 menunjukkan perbedaan intensitas myalgia setelah dilakukan intervensi pada kelompok intervensi dan kelompok kontrol dengan selisih 0,81 ( $p$ value $=$ 0,001).

Tabel 1. Perbedaan rerata intensitas myalgia antara responden pada kelompok intervensi dan kelompok kontrol sebelum dan sesudah diberikan PMR ( n=32)

\begin{tabular}{llll}
\hline Variable & Pengukuran & $\begin{array}{l}\text { Median } \\
\text { (Min- } \\
\text { Max) }\end{array}$ & $\begin{array}{l}p \\
\text { value }\end{array}$ \\
\hline Intensitas & Pre & $\begin{array}{l}3,5 \\
(3-4)\end{array}$ & \\
$\begin{array}{l}\text { myalgia } \\
\text { kelompok }\end{array}$ & Post & $\begin{array}{l}2,0 \\
(1-2)\end{array}$ & \multirow{2}{*}{0,001} \\
kontrol & & $\begin{array}{l}4,0 \\
(3-4)\end{array}$ & \\
Intensitas & Pre & 1,0 & \\
$\begin{array}{l}\text { myalgia } \\
\text { kelompok }\end{array}$ & Post & $(0-1)$ & \\
intervensi & & & \\
\hline
\end{tabular}

Tabel 2. Perbedaan rerata intensitas myalgia antara responden pada kelompok intervensi dan kelompok kontrol sesudah diberikan PMR $(\mathbf{n}=32)$

\begin{tabular}{lllr}
\hline Variable & $\begin{array}{c}\text { Mean } \\
\pm \text { SD }\end{array}$ & $\begin{array}{l}\text { Median } \\
\text { (Min-Max) }\end{array}$ & $p$ value \\
\hline $\begin{array}{l}\text { Intensitas } \\
\text { Myalgia }\end{array}$ & $1,69 \pm 0,479$ & $2,0(1-2)$ & \\
$\begin{array}{l}\text { Kelompok } \\
\text { kontrol }\end{array}$ & & & 0,001 \\
\cline { 1 - 1 } $\begin{array}{l}\text { Intensitas } \\
\begin{array}{l}\text { Myalgia } \\
\text { Kelompok } \\
\text { intervensi }\end{array}\end{array}$ & $0,88 \pm 0,324$ & $1,0(0-1)$ & \\
\hline
\end{tabular}

\section{PEMBAHASAN}

Rerata usia responden pada penelitian ini adalah berusia 40 tahun ke atas sebanyak $75 \%$. Hal ini juga didukung dengan penelitian menurut Hulma (2014) menyatakan bahwa 97\% pasien kanker paru berusia 40 tahun 
ke atas. Menurut Doherty (2001) bahwa semakin bertambahnya usia maka akan semakin berkurangnya masa otot yang akan berpengaruh terhadap kekuatan otot.

Penurunan fungsi fisiologis, perubahan oksidatif jaringan otot dan faktor sosial budaya mempengaruhi sensitifitas myalgia pada usia tua, sehingga sensitifitas nyeri menurun dibandingkan pada usia muda (Bennet, 2002). Menurut Hensing (2003) myalgia yang terjadi setelah pemberian kemoterapi dengan carboplatin dan paclitacsel pada usia kurang dari 70 tahun dan diatas 70 tahun mempunyai toksisitas yang sama. Efek samping kemoterapi tidak dipengaruhi oleh usia, karena frekuensi dan beratnya toksisitas berkaitan dengan dosis obat, jadwal pemberian dan penyakit penyerta yang dialami, sehingga dalam pemberian kemoterapi harus menggunakan pengukuran dosis yang spesifik untuk mencegah dan meminimalkan toksisitas (Yarbro et al, 2011).

Mayoritas responden pada penelitian ini baik pada kelompok kontrol maupun intervensi adalah berjenis kelamin laki-laki yaitu 81,25 \% dengan perokok aktif. Penelitian yang dilakukan Yosida et al (2009) adalah pasien kanker paru dengan jenis kelamin laki-laki sebanyak 82 $\%$. Menurut Davey (2006) faktor risiko kanker paru yang paling umum adalah merokok, di mana perokok berat mempunyai peluang sekitar 10 kali lebih besar mengalami kanker paru di banding bukan perokok.

Menurut Riskesdas (2013) perilaku merokok penduduk Indonesia 15 tahun keatas dari 2007 ke 2013, cenderung meningkat $36,3 \%$ yaitu $64,9 \%$ pada laki-laki dan 2,1\% pada perempuan. Sebagian besar kanker paru berisiko terjadi pada laki-laki, karena faktor merokok lebih banyak pada laki-laki sehingga asap rokok yang berdampak terhadap jaringan paru-paru sehingga memicu terjadinya kanker paru. Semakin lama dan semakin banyak rokok yang dikonsumsi maka akan semakin tinggi risiko terjadi kanker paru (Cahyono, 2008).

Penatalaksanaan kanker paru yaitu 
dengan pembedahan, radioterapi dan kemoterapi (PDPI, 2011). Salah satu efek samping kemoterapi adalah myalgia (Yarbro, Vucik \& Gobel, 2014). Menurut Mense \& Simon (2001) perempuan lebih sensitif dibandingkan laki-laki terhadap myalgia.

Sensitifitas myalgia selain dipengaruhi oleh kekuatan otot, dipengaruhi juga oleh ketebalan otot. Otot laki-laki lebih kuat dibandingkan dengan otot perempuan (Cardoso, 2011). Selain itu otot laki-laki juga lebih tebal dibandingkan perempuan (Kubo et al, 2003). Semakin kuat dan tebal otot individu maka sensitifitas myalgia akan menurun (Pain, 2011).

Sebagian besar myalgia terjadi pada siklus kemoterapi kurang dari 3. Berdasarkan penelitian menurut Loprinzi, Duffy \& Ingle (1993) yaitu myalgia terjadi pada kemoterapi siklus kedua sampai siklus keempat. Hal yang sama diungkapkan oleh Straus (2004) bahwa myalgia akibat efek samping kemoterapi dengan carboplatin dan paclitacsel yaitu pada siklus kedua sampai siklus keempat. Keluhan myalgia setelah pemberian kemoterapi bervariasi dari satu siklus kemoterapi dengan siklus berikutnya yaitu dari tingkat ringan sampai berat dan pada setiap siklus kemoterapi pasien akan merasakan myalgia (Yarbro, Vucik \& Gobel, 2014).

Sebagian besar obat kemoterapi yang digunakan adalah carboplatin dan paclitacsel yaitu sebanyak $68,75 \%$ dan yang menggunakan carboplatin dan etoposide yaitu sebanyak $31,25 \%$. Pada penelitian yang dilakukan oleh Yoshida et al (2009) yaitu obat kemoterapi yang digunakan pada pasien kanker paru yaitu carboplatin dan paclitacsel $(\mathrm{n}=50)$. Paclitacsel dapat menimbulkan myalgia (Yarbro, Vucik \& Gobel, 2014).

Myalgia akibat pemberian kemoterapi paclitacsel terjadi karena tertimbunnya sampah metabolik di dalam otot yang menyebabkan iritasi sehingga terjadi spasme otot yang menimbulkan rasa nyeri dan pegalpegal pada otot. Selain itu akan menyebabkan terjadinya peningkatan kadar kalsium di intrasel, mendorong sitoksisitas ke dalam akson dan 
badan sel saraf yang mengakibatkan reaksi inflamasi dan elevasi enzim otot yaitu kreatinin phospokinase yang menyebabkan injuri otot sehingga akan menimbulkan myalgia (Yarbro, Vucik \& Gobel, 2014).

Intensitas myalgia pada penelitian ini antara lain myalgia ringan (sakala 3) yaitu $40,62 \%$ dan myalgia sedang (skala 4) yaitu 59,37\%. Hal ini didukung dengan penelitian yang dilakukan oleh Yosida et al (2009) yang dilakukan pada 50 responden dan didapatkan myalgia ringan sebanyak 34\%, myalgia sedang yaitu $44 \%$, myalgia berat yaitu $24 \%$ dan tidak ada keluhan myalgia sebanyak $28 \%$. Obat kemoterapi yang diberikan dengan dosis tunggal dan dosis tinggi akan mempengaruhi tingkat keparahan myalgia (Garisson, 2003). Semakin tinggi dosis obat kemoterapi yang diberikan maka akan semakin tinggi keluhan myalgia yang dirasakan oleh pasien.

Pada penelitian ini sebagian besar obat analgetik yang digunakan golongan nonopioid yaitu asam mefenamat sebanyak $90,6 \%$ dan paracetamol sebanyak $0,09 \%$. Penelitian yang dilakukan Yoshida et al (2009) bahwa obat analgetik yang digunakan pada pasien kanker paru yang dilakukan kemoterapi dengan myalgia adalah non opiod NSAID's $(n=50)$.

Analgetik merupakan metode yang paling umum untuk mengatasi nyeri. Analgetik terbagi menjadi tiga jenis yaitu : opioid dan obat tambahan (adjuvan) atau ko-analgesik, non narkotik (nonopioid) dan obat inflamasi nonsteroid (NSAIDs), (Muttaqin, 2010). Analgetik non opioid adalah paracetamol dan NSAID's yang bekerja pada rangsang nyeri pada bagian saraf (Jong, 2005). Ada tujuh kelompok NSAIDs antara lain : aspirin, derivat asam para klorobenzoat, derivat pirazolan, derivat asam proprionat, oksikam, asam fenilasetat dan fenamat (Hayes \& Kee, 1996). Asam mefenamat digunakan sebagai analgetik dan antiinflamasi (Rahardja, 2004). Obat yang diberikan pada pasien myalgia akibat pemberian kemoterapi paclitacsel yaitu nonopioid untuk myalgia ringan dan sedang, obat opioid untuk myalgia berat (Yarbro, Vucik \& Gobel, 2014).

Hasil uji statistik menunjukkan bahwa ada pengaruh PMR terhadap 
myalgia pada kelompok intervensi ( $p$ value $=0.001)$. Hal tersebut menunjukkan bahwa penurunan intensitas myalgia merupakan pengaruh dari perlakuan progressive muscle relaxation pada kelompok intervensi. Penelitian yang dilakukan oleh Pathak (2013) menunjukkan bahwa PMR efektif menurunkan nyeri dan fatigue pada pasien kanker yang menjalani radioterapi ( $p$ value $<0.001)$.

Pada saat dilakukan PMR, mekanisme pertahanan ditutup, sehingga pesan yang dihasilkan akan menstimulasi mekanoreseptor yang akan membuka pertahanan dan mempersepsikan nyeri. Saat impuls nyeri dihantarkan ke otak, PMR memodifikasi nyeri dengan merangsang sekresi endorfin yang akan menghambat pelepasan substansi P (Rohads, 2013). Saat endorfin dikeluarkan maka akan memblokir lepasnya substansi P dari neuron sensorik sehingga sensasi nyeri menjadi berkurang (Potter \& Perry, 2008).

\section{KESIMPULAN}

Hasil penelitian menunjukkan pemberian progressive muscle relaxation (PMR) terhadap penurunan myalgia pada pasien kanker paru yang menjalani kemoterapi adalah signifikan $(\mathrm{p}<0,05)$ dan didapatkan selisih penurunan intensitas myalgia yang bermakna antara kelompok yang tidak mendapatkan PMR dan kelompok yang yang diberikan PMR yaitu 0.81. Hal tersebut membuktikan bahwa tindakan PMR efektif dalam membantu menurunkan myalgia pada pasien kanker paru yang menjalani kemoterapi.

\section{SARAN}

Hasil penelitian menguatkan bahwa terapi PMR menjadi komplementer keperawatan mandiri dan memperkaya asuhan keperawatan yang berkualitas yang menjadi inspirasi untuk penelitian selanjutnya dalam menggali intervensi keperawatan klinik terkait myalgia. Pada penelitian yang akan datang perlu antisipasi dalam melakukan observasi dan evaluasi langsung 
segera setelah PMR dilakukan, selain itu juga perlu dikaji faktorfaktor yang mempengaruhi myalgia.

\section{DAFTAR PUSTAKA}

Badan Penelitian dan Pengembangan Kesehatan. (2013). Laporan hasil riset kesehatan dasar (RISKESDAS) Indonesia-tahun 2013. Diakses dari depkes.go.id/downloads/riskes das 2

013/Hasil\%20Riskesdas\%2020 13. $p d f$

Bennet, R. M. (2002). The clinical neurobiologi of fibromialgia and myofascial pain : therapeutic implications. USA : The Haworth Medical Press.

Black, J.M., \& Hawk, J.H. (2014). Medical surgical nursing: clinical management for positif outcomes.8th Edition. St. Louis: Elsevier Inc

Cahyono. (2008). Gaya hidup dan penyakit modern. Yogyakarta : Penerbit Kanisius

Cardoso, F.D.S., Curtolo, M., Natour, J., \& Junior, I.L., (2011). Assesment of quality of life, muscle strength and functional capacity in women with fibromyalgia. Brazil : Elsevier Revista brasileira de rematologi 2011;5(4) : 338

Davey, P. (2006). At a glance medicine. Jakarta: Erlangga
Falk, S., \& Williams. (2010). Lung cancer 3th Edition. New York: Oxford University press

Greenberg, J.S. (2002). Comprehensive stress management. 7th Edition. United States:Mc Graw Hill Company Inc

Handoko (2008). Pengobatan alternative. Jakarta: PT Elex Media Komutindo

Hayes, R., \& Kee, J.L., (1996). Farmakologi proses keperawatan. Jakarta : EGC

Hensing, T.A., Peterman, A.H., Schell, M.J., Lee, J.H., \& Socinski, M.A. (2003). The impact of age on toxicity, response rate, quality of life, and survival in patients with advanced, stage IIIb or iv nonsmall cell lung carcinoma treated with carboplatin and paclitaxel. Chicago : Center on Outcomes Research and Education,Northwestern University.

Hulma, M.A., Basyar, M., \& Mulyani, H. (2014). Hubungan karakteristik penderita dengan gambaran sitopatologi pada kasus karsinoma paru yang dirawat di RSUP Dr M Jamil Padang. Padang : Jurnal FK Unand

Jong W. (2005). Kanker, apakah itu: pengobatan, harapan hidup dan dukungan keluarga. Jakarta: Arcan Kubo, K., Kanehisa, H., Azuma, K.,Ishizu, M., Kuno, S.Y., Okada, M., \& Fukunaga, K.

JKH/ Volume 2/ Nomor 2/Juli 2018 (ISSN: 2548-1843, EISSN: 2621-8704) 
(2003). Muscle architectural characteristics in young and elderly men and women. Japan : US National Library Of Medicine National Institut of Health.

Loprinzi, C.L., Duffy., \& Ingle. (1993). Postchemotherapy rheumatism USA : American Society of Clinical Oncology

Mense, S. \& Simons, D. (2001). Muscle pain : Understanding its nature, diagnosis and treatment. Philadelpia USA : Lippincott Williams \& Wilkins

Muttaqin. (2008). Asuhan keperawatan klien dengan gangguan sistem persarafan Jakarta: Salemba Medika

Otto, S.E. (2001). Oncologi Nursing. $\left(4^{\text {nd }} E d\right)$. St Louis: Mosby Inc.

Pain, C.J. (2011). Effects of adipose thickness and muscle hardness on pressure pain sensitivity. USA : Pubmed.

Pathak, P., Mahal., Kohli A., Nimbron. (2013). Progressive muscle relaxation : an adjuvant therapy for reducing pain and fatigue among hospitalized cancer patients receiving raditherapy. International journal of nursing studies, 2(2)58-65. Diunduh tanggal 15 februari 2015

PDPI. (2011). Kanker Paru: Pedoman Diagnosis dan Penatalaksanaan di Indonesia.
Jakarta: Balai Penerbit FKUI.

Philips. (2013). Antibody drug conjugates and imunotoxins : from pre clinical developement to therapeutic applications. South San Fransisco, CA, USA : Springer New York Heidelberg Dordrecht London

Potter, P.A., \& Perry, A.G. (2008). Fundamental of nursing : concepts, process and practice. St. Lois Missiouri: Mosby Company.

Rahardjo, R. (2004). Kumpulan kuliah farmakologi. Jakarta : EGC

Rohads C.J,. (2013). Mechanism of pain relief through tai chi and qigong. USA : J Pain An Open Access Journal. 2(1): 115

Rohkamm (2003). Colour atlas of neurology. German: Georg Thieme verlag

Smeltzer, S.C., Bare, B.G., Hinkle, J.L., Cheever, K.H. (2008). Brunner \& Suddarth,s textbook of medical surgical nursing. (12th ed.). Philadelpia : Lippincott William \& Wilkins

Straus, G.M., Herndon, J., Maddaus, A., Johnstone, D.W., Johnson, E.A., Watson, D.M., Sugarbaker, R.L., Schilsky, R.L. \& Green, M.R. (2004). Randomized clinical trial of adjuvant chemotherapy with paclitacxel and carboplatin following resection in stage IB non small cell lung cancer (NSCLC): Report of Cancer and Leukemia Group B

JKH/ Volume 2/ Nomor 2/Juli 2018 (ISSN: 2548-1843, EISSN: 2621-8704) 
(CALGB) Protocol 9633. America : Journal of Clinical Oncology

Strong J., Wright A., Unruh ,Baxter (eds). 2002 . Pain: A Textbook for Therapist. London: Churchil Livingstonepp : 4-19.

Tjay \& Rahardja. (2007). Obat-obat Penting, PT Gramedia, Jakarta.

World Health Organization (2013). Cancer. Available from: http://www.who.int/topics/can cer/e n/index.html. Diunduh tanggal 1 April 2014.

Yarbro, C.H., Wujcik, D. \& Gobel, B.H (2014). Cancer symptom management. (4th Ed.). United States Of America: Jones \&
Bartlett Learning,LL.

Ylimaz, U., Polat, G., Anar, C. \& Halilcolar. (2011). Carboplatin plus etoposide for extensive stage small-cell lung cancer: an experience with AUC 6 doses of carboplatin. India: Indian $J$ Cancer

Yoshida, T,. Sawa, T., Ishiguro, T., Horiba, A., Minatoguchi, S., \& Fujiwara, H (2009). The efficacy of prophylactic shakuyaku kanzo to for myalgia and arthralgia following carboplatin and paclitaxel combination chemotherapy for non small cell lung cancer. Japan: Second department of internal medicine 